\title{
Production and consumption of dimethylsulfide (DMS) and dimethylsulfoniopropionate (DMSP) in a diatom-dominated intertidal sediment
}

\author{
S. A. van Bergeijk ${ }^{1, *}$, K. Schönefeldt ${ }^{1}$, L. J. Stal ${ }^{2}$, J. Huisman ${ }^{1}$ \\ ${ }^{1}$ Aquatic Microbiology, Institute for Biodiversity and Ecosystem Dynamics, University of Amsterdam, \\ Nieuwe Achtergracht 127, 1018 WS Amsterdam, The Netherlands \\ ${ }^{2}$ Netherlands Institute of Ecology, Center for Estuarine and Coastal Ecology, PO Box 140, 4400 AC Yerseke, The Netherlands
}

\begin{abstract}
Intertidal sediments usually contain a high amount of dimethylsulfoniopropionate (DMSP) and therefore represent environments with a potentially high emission of dimethylsulfide (DMS). However, knowledge on production and release of DMSP in intertidal sediments is limited. Here, we present data on the diel variation of the total DMS and DMSP content (DMS[P $]_{\text {total }}$ ) and the DMS(P) concentration in the porewater $\left(\mathrm{DMS}[\mathrm{P}]_{\text {porewater }}\right)$ in an intertidal sediment covered by diatoms. Measurements were made at low tide during the day and during the night. Both DMS(P) total and $\mathrm{DMS}(\mathrm{P})_{\text {porewater }}$ were constant and did not respond to the changing conditions of light and oxygen in the sediment, indicating that production and consumption processes were in equilibrium. Incubation of diatoms under light/oxic, dark/oxic and dark/anoxic conditions suggested that no large amounts of DMSP were excreted under the different conditions applied. DMS $(\mathrm{P})_{\text {porewater }}$ was around $100 \mathrm{nM}$, which was about 3 orders of magnitude lower than DMS(P $)_{\text {total }}$. Only after the onset of a heavy rainfall $\mathrm{DMS}(\mathrm{P})_{\text {porewater }}$ in the sediment suddenly increased above $1 \mu \mathrm{M}$, which was explained by excretion of DMSP by DMSP-containing microorganisms in response to the osmotic shock. Both DMSP and DMS were rapidly degraded in sediment slurries, especially under oxic conditions, and degradation closely followed first order kinetics. We conclude that although intertidal sediments contain high total amounts of DMSP, a relatively low amount of DMSP is released by the microphytobenthos under naturally fluctuating light and oxygen conditions, and once released, DMSP and DMS are rapidly degraded in the upper oxygenated sediment. This explains the low flux of DMS from intertidal sediments to the atmosphere reported in the literature.
\end{abstract}

KEY WORDS: Dimethylsulfoniopropionate (DMSP) - Dimethylsulfide (DMS) - Intertidal sediment · Diatoms $\cdot$ Degradation rates $\cdot$ Diel variation

Resale or republication not permitted without written consent of the publisher

\section{INTRODUCTION}

Dimethylsulfide (DMS) is one of the major biogenic sources of sulfur to the atmosphere (Kelly \& Smith 1990, Bates et al. 1992). Increasing knowledge of the impact of atmospheric oxidation products of DMS on climate (Charlson et al. 1987, Charlson \& Wigley 1994,

*Present address: Departamento de Biología, Facultad de Ciencias del Mar, Universidad de Cádiz, Campus Rio San Pedro S/N, 11510 Puerto Real, Spain. E-mail: stef.van@uca.es
Andreae et al. 1995, Ayers et al. 1997) has stimulated research on processes leading to DMS emission over the past years. DMS is mainly emitted from the marine environment (Bates et al. 1992). This is a consequence of the fact that DMS is the cleavage product of dimethylsulfoniopropionate (DMSP), which is a secondary metabolite known to be present in many marine micro- and macroalgae (White 1982, Keller et al. 1989, Blunden et al. 1992).

Jonkers et al. (1998a) suggested that marine microbial mats are appropriate model ecosystems to study 
processes and factors that determine emission rates of DMS. High concentrations of DMSP have been measured in these intertidal sediment systems (Visscher et al. 1991, 1994, Van Bergeijk \& Stal 1996, Jonkers et al. 1998a) and they contain high numbers of microorganisms that are involved in the production and consumption of DMSP and DMS (Jonkers et al. 1998a). The oxygenic phototrophic microorganisms or microphytobenthos, which grow in the top layer of the sediment, generally consist of cyanobacteria and diatoms. DMSP production has recently been detected in several benthic diatoms (Jonkers et al. 1998a, Van Bergeijk 2000) and they are probably responsible for a substantial part of the total DMSP in the sediment. Release of DMSP from microphytobenthos to the environment provides a substrate for bacteria present in the sediment. As oxygen penetrates only a few mm into the sediment (e.g. Revsbech et al. 1980), DMSP is degraded both under oxic and anoxic conditions. DMSP is degraded either via cleavage or demethylation (Taylor \& Visscher 1996). Cleavage of DMSP yields DMS and acrylate, while methylmercaptopropionate (MMPA) is the initial product of demethylation of DMSP. Both DMS and MMPA, in turn, are degraded under oxic as well as anoxic conditions. Most research has focused on the degradation routes of DMSP and the microorganisms involved (e.g. Taylor \& Gilchrist 1991, Taylor \& Visscher 1996, Van der Maarel \& Hansen 1996 and references within) but little is known about the production and release of DMSP in intertidal sediments. Microbial communities in intertidal sediments are exposed to large diel fluctuations in physico-chemical parameters (e.g. oxygen, $\mathrm{pH}$, salinity, light). How these fluctuations affect the dynamics of the particulate, microphytobenthos-related DMSP pool and the dissolved DMSP pool has not been investigated. In the present study, we measured these pools in relation to the microphytobenthic biomass, expressed as chl $a$, at low tide during the day and night, in an intertidal sediment covered by benthic diatoms. To obtain an estimate of production and consumption rates, the potential degradation rates of DMSP and DMS in this sediment were assessed in slurry experiments.

\section{MATERIALS AND METHODS}

Sampling. The diel variation of $\mathrm{DMS}(\mathrm{P})$ and $\operatorname{chl} a$ was determined at an intertidal flat at Ellewoutsdijk in the Westerschelde Estuary, The Netherlands (latitude $51^{\circ} 23^{\prime} \mathrm{N}$, longitude $3^{\circ} 49^{\prime} \mathrm{E}$ ), on 29 and 30 June 1998. The sediment (water content $43.5 \%$, specific gravity $1.55 \mathrm{~g} \mathrm{~cm}^{-3}$ wet wt) was covered with a film of diatoms, consisting mainly of epipelic species, dominated by Gyrosigma acuminatum and Navicula phyllepta. Sal- inity was $30 \mathrm{PSU}$ and temperature was $19^{\circ} \mathrm{C}$ during the day and $16^{\circ} \mathrm{C}$ during the night. Total DMS(P) and $\mathrm{DMS}(\mathrm{P})$ in the porewater were measured. Total DMS(P) (indicated as DMS $[\mathrm{P}]_{\text {total }}$ ) is the total amount of particulate and dissolved DMS and DMSP in the sediment. DMS $(\mathrm{P})_{\text {total }}$ was measured because preliminary measurements showed that total DMS and dissolved DMSP concentrations were generally below detection limit (see 'DMS[P] analysis'), whereas the majority of DMS(P) was in the form of particulate DMSP. $\mathrm{DMS}(\mathrm{P})_{\text {porewater }}$ is the total concentration of extracellular, dissolved DMS and DMSP. Samples were taken at low tide, during the day and night, at regular time intervals in 6 comparable plots of approximately $0.5 \mathrm{~m}^{2}$. To investigate the effect of inhibition of photosynthesis on the DMS(P) concentration in the sediment, 3 of the plots were incubated in the dark using plastic crates $(1.0 \times 0.5 \times 0.2 \mathrm{~m})$ covered with black plastic. The crates were open on 1 side, which was put on the sediment surface. The plastic crates were removed after sampling during the day, just before submersion of the sediment. In each plot, 3 cores $(\varnothing 24 \mathrm{~mm})$ were taken and 2 sediment slices ( 0 to 2.5 and 2.5 to $5 \mathrm{~mm}$ depth) were sampled with a $2.5 \mathrm{~mm}$ high perspex ring ( $\varnothing 24 \mathrm{~mm}$ ) for determination of $\operatorname{DMS}(\mathrm{P})_{\text {total }}$ and chl a. The $2.5 \mathrm{~mm}$ slices were cut in half with a small spatula. One half was used for chl $a$ analysis and the other half was used for determination of DMS $(P)_{\text {total }}$. Samples of the 3 cores from each plot were pooled in order to average the sediment samples. Samples for chl a analysis were put in glass culture tubes, covered with parafilm and stored on ice in the dark. The tubes were immediately transferred to a freezer $\left(-80^{\circ} \mathrm{C}\right)$ upon return to the laboratory and stored until analysis. Samples for determination of $\mathrm{DMS}(\mathrm{P})_{\text {total }}$ were put in $6 \mathrm{ml}$ glass vials (Chrompack). Filtered seawater from the sampling site (GF/F filters, Whatman) was added to a final volume of $3 \mathrm{ml}$, after which $1 \mathrm{ml} 8 \mathrm{M} \mathrm{NaOH}$ was added. DMS(P) concentration in the filtered seawater was below detection limit. After addition of $\mathrm{NaOH}$, the vials were immediately closed with gas-tight, Teflon-coated butyl rubber septa and aluminum crimp seal caps. The vials were stored at room temperature in the dark and the samples were analyzed for $\operatorname{DMS}(\mathrm{P})_{\text {total }}$ within $1 \mathrm{wk}$ after sampling. DMS(P) porewater was sampled using Rhizon Soil Moisture Samplers (SMS, Eijkelkamp Agrisearch Equipment). An SMS consisted of a ceramic rod (length $50 \mathrm{~mm}, \varnothing 2 \mathrm{~mm}$ ) connected to a $10 \mathrm{ml}$ syringe, which was used to apply a vacuum. Porewater was absorbed by the ceramic rod and collected in the syringe. At each sampling point the ceramic rod of an SMS was inserted in each plot just below the sediment surface and was removed $1 \mathrm{~h}$ after insertion. As we did not have the necessary equipment at our disposal in the field, we could not measure DMS and DMSP separately 
and therefore measured DMS(P) $)_{\text {porewater }}$ To $4.5 \mathrm{ml}$ of porewater, $1.5 \mathrm{ml}$ of $8 \mathrm{M} \mathrm{NaOH}$ was added in $6 \mathrm{ml}$ glass vials, which were sealed immediately. The samples were stored at $4^{\circ} \mathrm{C}$ in the dark until analysis.

Slurry experiments. To determine the potential degradation rate of extracellular DMSP and DMS, sediment slurries were amended with $7 \mu \mathrm{M}$ DMSP and incubated under oxic/light, oxic/dark and anoxic/dark conditions. These experiments were run in duplicate (Series A and Series B). The slurries were prepared with sediment collected using stainless steel cores (Ø $24 \mathrm{~mm}$ ) during low tide on 30 June 1998. The top $1 \mathrm{~cm}$ of sediment from each core was mixed with $25 \mathrm{ml}$ of filtered seawater (GF/F filters, Whatman) in a $60 \mathrm{ml}$ glass bottle. Slurries heated at $110^{\circ} \mathrm{C}$ for 45 min were used as abiotic controls. The bottles were closed gastight, using $10 \mathrm{~mm}$ thick butyl rubber stoppers and aluminum crimp caps. Prior to the experiments butyl rubber stoppers were boiled in $1 \mathrm{M} \mathrm{NaOH}$ and rinsed with demineralized water, to remove sulfur compounds that could be present in the stoppers. Anoxic/dark conditions were obtained by wrapping the bottles with aluminum foil and flushing the headspace with $\mathrm{N}_{2}$ gas for $30 \mathrm{~min}$. For oxic/dark conditions the bottles were wrapped with aluminum foil and incubated on a shaking incubator $(200 \mathrm{rpm})$. For oxic/light conditions the bottles were illuminated at a photon flux density of approximately $75 \mu \mathrm{mol}$ photons $\mathrm{m}^{-2} \mathrm{~s}^{-1}$ and incubated on the same shaking incubator. All slurries were incubated at $20^{\circ} \mathrm{C}$. The DMS concentration in the slurries was followed by measuring DMS in the headspace of the bottles. At regular time intervals, $1.5 \mathrm{ml}$ of slurry was sampled for DMSP using plastic syringes fitted with stainless steel needles. Immediately after sampling the samples were centrifuged for 2 min (Eppendorf centrifuge, $12000 \mathrm{~g}$ ) and the supernatant was used for measuring extracellular DMSP. The supernatant was purged with $\mathrm{N}_{2}$ for 7 min to remove DMS and $0.75 \mathrm{ml}$ was put in $6 \mathrm{ml}$ glass vials, after which $0.25 \mathrm{ml}$ $\mathrm{NaOH}(8 \mathrm{M})$ was added and the vials were sealed. Standards of DMS were incubated parallel to the slurries in equally sized bottles containing an equal amount of liquid. When the slurries were sampled for DMSP analysis, samples of $1.5 \mathrm{ml}$ were taken from the standards simultaneously, to correct for changes in the liquid to headspace volume ratio.

A natural population of microphytobenthos, consisting of benthic diatoms, was also incubated under light/ oxic, dark/oxic and dark/anoxic conditions to evaluate the effect of these treatments on the intracellular and extracellular DMSP concentration. Diatoms were extracted from the sediment using silica slurry, after the method described by Blanchard et al. (1997). The slurry was obtained from sediment collected near our sampling site on 27 April 1998. Salinity and tempera- ture at the sampling site were $20 \mathrm{PSU}$ and $13^{\circ} \mathrm{C}$, respectively. The sediment was densely covered by epipelic diatoms. In $30 \mathrm{ml}$ glass bottles, $5 \mathrm{ml}$ silica slurry, containing the diatoms, was mixed with $10 \mathrm{ml}$ filtered seawater. The bottles were sealed and incubated for $24 \mathrm{~h}$ as described above. Samples were taken before and after incubation.

Chl $\boldsymbol{a}$ analysis. Chl a was determined spectrophotometrically. Before chl a extraction, the sediment samples were freeze-dried for $48 \mathrm{~h}$. Chl a was extracted overnight at $4{ }^{\circ} \mathrm{C}$ with $\mathrm{N}, \mathrm{N}$-dimethylformamide (DMFA), after vortexing and ultrasonicating for $10 \mathrm{~min}$ in a cold water bath. After extraction, the samples were centrifuged for $5 \mathrm{~min}$ and the extinction was measured at $665 \mathrm{~nm}$ in $1 \mathrm{ml}$ of DMFA extract in a glass cuvette. Subsequently, $10 \mu \mathrm{l}$ of $4 \mathrm{M} \mathrm{HCl}$ was added to convert chl a to phaeophytin $a$. The sample was mixed and the extinction at $665 \mathrm{~nm}$ was measured again. The chl $a$ and phaeophytin a concentrations were calculated according to the following equations (De Winder et al. 1999): $\operatorname{chl}$ a $\left(\mathrm{g} \mathrm{l}^{-1}\right)=\left(2.3 \times\left[E_{\mathrm{N}}-\right.\right.$ $\left.\left.E_{\mathrm{A}}\right]\right) / 72.114$ and phaeophytin $a\left(\mathrm{~g} \mathrm{l}^{-1}\right)=(2.3 \times[1.8 \times$ $\left.\left.E_{\mathrm{A}}-E_{\mathrm{N}}\right]\right) / 72.114$, where $E_{\mathrm{N}}$ and $E_{\mathrm{A}}$ are the extinctions measured before and after the addition of $\mathrm{HCl}_{\text {, }}$ respectively and $72.114\left(\mathrm{l} \mathrm{g}^{-1} \mathrm{~cm}^{-1}\right)$ is the absorption coefficient of chl $a$ in DMFA.

DMS(P) analysis. DMSP was measured indirectly as DMS, after hydrolysis of DMSP to DMS and acrylate with cold alkali (Challenger et al. 1957, White 1982). A final concentration of $2 \mathrm{M} \mathrm{NaOH}$ was used to hydrolyze the samples, which were incubated for at least $24 \mathrm{~h}$ before analysis. DMS was measured by headspace analysis with a gas chromatograph (CP 9000, Chrompack), equipped with a wide bore column (Poraplot U, ID $0.53 \mathrm{~mm} ; 25 \mathrm{~m}$; Chrompack) and a flame ionization detector (FID). Temperatures of the detector, injector and oven were 200, 175 and $150^{\circ} \mathrm{C}$, respectively. The flows of air, $\mathrm{H}_{2}$ and the carrier gas, $\mathrm{N}_{2}$, were 300,30 and $8 \mathrm{ml} \mathrm{min}{ }^{-1}$, respectively. The retention time of DMS was approximately $2.5 \mathrm{~min}$. The system was calibrated using standard solutions of either DMS or DMSP (cleaved to DMS by alkaline hydrolysis), which were sampled parallel to the samples in the same bottles with the same headspace: volume ratios. The detection limit of this method was $10 \mathrm{nM}$ in samples of $3 \mathrm{ml}$ in $6 \mathrm{ml}$ vials and accurate DMS measurements could be made above $100 \mathrm{nM}$. Preliminary measurements showed that extracellular DMS and DMSP concentrations in the porewater of intertidal sediments were generally below or just above the detection limit. To be able to measure the concentration of DMS(P) in the porewater samples, we used the purge-and-trap system developed by Brugger et al. (1998), with a detection limit of $0.33 \mathrm{nM}$ for a $3 \mathrm{ml}$ sample. 
untreated plots
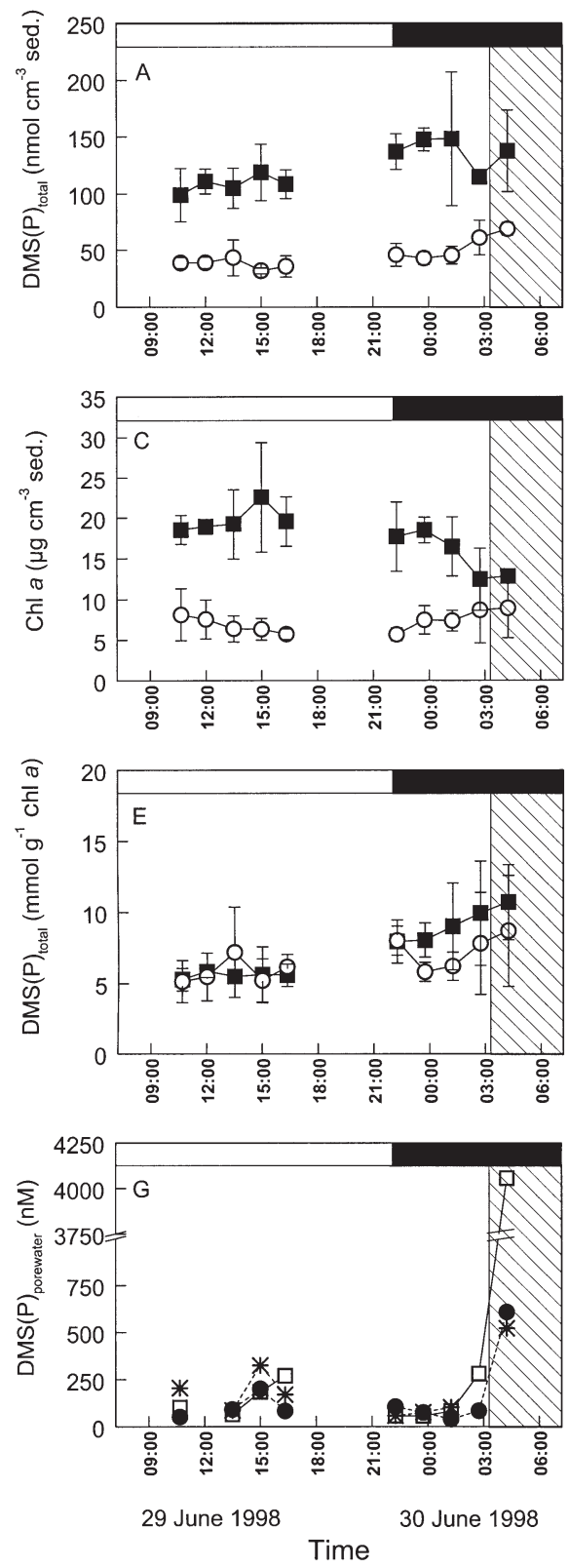

darkened plots
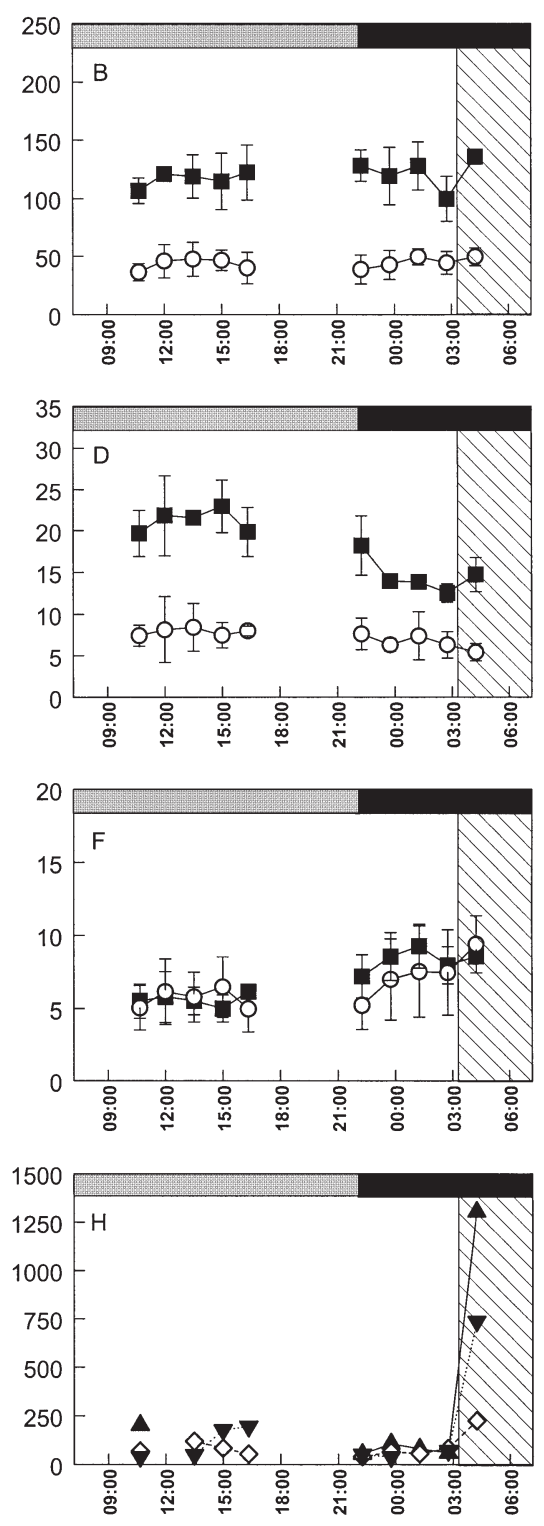

29 June 1998

30 June 1998

Fig. 1. Diurnal variation in $\operatorname{DMS}(\mathrm{P})_{\text {total }}$ content $(\mathrm{A}, \mathrm{B})$, chl a $(\mathrm{C}, \mathrm{D})$, chl a-specific DMS(P) content $(\mathrm{E}, \mathrm{F})$ and extracellular $\mathrm{DMS}(\mathrm{P})$ $(\mathrm{G}, \mathrm{H})$, measured in a diatom-dominated intertidal flat of the Westerschelde Estuary on 29 and 30 June 1998, during low tide. The sediment was covered with water during high tide from 17:00 until 21:30 h. White bars on top: light period (average light intensity: 500 umol photons $\mathrm{m}^{-2} \mathrm{~s}^{-1}$ ); black bars on top: dark period; gray bars on top: sediment covered by black plastic during the light period. a: 0 to $2.5 \mathrm{~mm}$ depth, O: 2.5 to $5 \mathrm{~mm}$ depth. Error bars: standard deviation of means of 3 sediment plots. In graphs $\mathrm{G}$ and $\mathrm{H}$ porewater data are shown separately for each of the 6 different plots; porewater data at 12:00 $\mathrm{h}$ are lacking. Hatched areas in the graphs indicate period of rainfall

\section{RESULTS}

Statistics. Two-way analysis of variance with Bonferroni post-hoc comparison (Software: SPSS 9.0) was applied to assess significant differences between the samples taken at low tide during the day and during the night. Fixed factors in the analysis were untreated versus darkened sediment plots, and time of sampling. Not all data met the demand of homogeneity of variance, as tested with Levene's test. This problem could not be alleviated by transformation of the data (log or square root). Hence, it was decided to use the non-transformed data for all statistical analyses, except for the data of $\operatorname{DMS}(\mathrm{P})_{\text {porewater }}$ for which a logarithmic transformation significantly improved homogeneity of variance.

The total DMS(P) content of the 2 top layers of sediment ( 0 to 2.5 and 2.5 to $5 \mathrm{~mm}$ ) was constant during the diel cycle (Fig. 1A,E). Only the total DMS(P) content of the last sampling point of the deeper layer (2.5 to $5 \mathrm{~mm}$ ) was slightly but significantly higher than that of the first sampling point (Table 1). Incubation of the sediment in the dark, by covering it with black plastic during the low water period in the light, had no significant effect on DMS(P) $)_{\text {total, }}$ on chl $a$ or on the chl $a$ specific DMSP content (Table 1, Fig. 1A-F). However, during the low water period in the dark, the chl a con- 
Table 1. Summary of results of 2-way analysis of variance. Factors are time of sampling (Time) and untreated versus darkened sediment plots (Treatment)

\begin{tabular}{|c|c|c|c|c|}
\hline & Source of variation & $\mathrm{df}$ & $F$ & p value \\
\hline $\mathrm{DMS}(\mathrm{P})_{\text {total }}(0$ to $2.5 \mathrm{~mm})$ & Time & 9 & 1.880 & 0.084 \\
\hline (nmol cm ${ }^{-3}$ sediment) & $\begin{array}{l}\text { Treatment } \\
\text { Time } \times \text { Treatment }\end{array}$ & $\begin{array}{l}1 \\
9\end{array}$ & $\begin{array}{l}0.295 \\
0.639\end{array}$ & $\begin{array}{l}0.590 \\
0.757\end{array}$ \\
\hline $\mathrm{DMS}(\mathrm{P})_{\text {total }}(2.5$ to $5 \mathrm{~mm})$ & Time & 9 & $2.735^{\mathrm{a}}$ & 0.014 \\
\hline (nmol cm ${ }^{-3}$ sediment) & $\begin{array}{l}\text { Treatment } \\
\text { Time } \times \text { Treatment }\end{array}$ & $\begin{array}{l}1 \\
9\end{array}$ & $\begin{array}{l}0.178 \\
1.590\end{array}$ & $\begin{array}{l}0.676 \\
0.151\end{array}$ \\
\hline $\begin{array}{l}\text { Chl a (0 to } 2.5 \mathrm{~mm}) \\
\left(\mu \mathrm{g} \mathrm{cm}^{-3} \text { sediment }\right)\end{array}$ & $\begin{array}{l}\text { Time } \\
\text { Treatment } \\
\text { Time } \times \text { Treatment }\end{array}$ & $\begin{array}{l}9 \\
1 \\
9\end{array}$ & $\begin{array}{l}6.642^{\mathrm{b}} \\
0.078 \\
0.792\end{array}$ & $\begin{array}{l}0.00001 \\
0.781 \\
0.626\end{array}$ \\
\hline $\begin{array}{l}\text { Chl a }(2.5 \text { to } 5 \mathrm{~mm}) \\
\left(\mu \mathrm{cm}^{-3} \text { sediment }\right)\end{array}$ & $\begin{array}{l}\text { Time } \\
\text { Treatment } \\
\text { Time } \times \text { Treatment }\end{array}$ & $\begin{array}{l}9 \\
1 \\
9\end{array}$ & $\begin{array}{l}0.199 \\
0.0003 \\
1.141\end{array}$ & $\begin{array}{l}0.993 \\
0.987 \\
0.358\end{array}$ \\
\hline $\operatorname{DMS}(\mathrm{P})_{\text {total }}(0$ to $2.5 \mathrm{~mm})$ & Time & 9 & $6.283^{\mathrm{b}}$ & 0.00002 \\
\hline$\left(\mathrm{mmol} \mathrm{g}{ }^{-1} \mathrm{chl} a\right)$ & $\begin{array}{l}\text { Treatment } \\
\text { Time } \times \text { Treatment }\end{array}$ & $\begin{array}{l}1 \\
9\end{array}$ & $\begin{array}{l}0.839 \\
0.479\end{array}$ & $\begin{array}{l}0.365 \\
0.880\end{array}$ \\
\hline $\operatorname{DMS}(\mathrm{P})_{\text {total }}(2.5$ to $5 \mathrm{~mm})$ & Time & 9 & 1.586 & 0.153 \\
\hline$\left(\mathrm{mmol} \mathrm{g}^{-1} \mathrm{chl} a\right)$ & $\begin{array}{l}\text { Treatment } \\
\text { Time } \times \text { Treatment }\end{array}$ & $\begin{array}{l}1 \\
9\end{array}$ & $\begin{array}{l}0.017 \\
0.578\end{array}$ & $\begin{array}{l}0.897 \\
0.807\end{array}$ \\
\hline $\begin{array}{l}\mathrm{DMS}(\mathrm{P})_{\text {porewater }} \\
(\mathrm{nM})\end{array}$ & $\begin{array}{l}\text { Time } \\
\text { Treatment } \\
\text { Time } \times \text { Treatment }\end{array}$ & $\begin{array}{l}8 \\
1 \\
8\end{array}$ & $\begin{array}{c}10.52^{\mathrm{b}} \\
4.02 \\
0.28\end{array}$ & $\begin{array}{l}0.0000005 \\
0.054 \\
0.968\end{array}$ \\
\hline${ }^{\mathrm{a}} \mathrm{p}<0.05 ;{ }^{\mathrm{b}} \mathrm{p}<0.001$ & & & & \\
\hline
\end{tabular}

tent of the top $2.5 \mathrm{~mm}$ of sediment was slightly but significantly lower at the last sampling points than at some points during the low water period in the light (Table 1, Fig. 1C,D). Simultaneous to this decrease in chl a we observed an increase in chl a-specific DMSP content, which was slightly but significantly higher in the top $2.5 \mathrm{~mm}$ at the last sampling points during the low water period in the dark (Table 1, Fig. 1E,F).

The low DMS(P) concentration in the porewater (Fig. 1G,H) indicated that the major part of DMS(P) total was present inside the diatoms (and other DMSPcontaining organisms which may have been present). $\operatorname{DMS}(\mathrm{P})_{\text {total }}\left(\sim 100 \mathrm{nmol} \mathrm{cm}{ }^{-3}\right.$ sediment or $\left.100 \mu \mathrm{M}\right)$ was 3 orders of magnitude higher than $\operatorname{DMS}(\mathrm{P})_{\text {porewater }}$ $(\sim 100 \mathrm{nM})$. DMS $(\mathrm{P})_{\text {porewater was constant during the tidal }}$ cycle, but suddenly increased to values $>1 \mu \mathrm{M}$ at the end of the low water period in the dark, which coincided with a heavy rainfall (Fig. 1G,H).

Silica slurry, containing a mixed population of diatoms extracted from intertidal sediment, was incubated under light/oxic, dark/oxic and dark/anoxic conditions, to simulate the light and oxygen conditions that occur in the sediment (Fig. 2). The intracellular DMSP content increased significantly in the light, but not in the dark (Fig. 2A). Because chl a did not change noticeably (Fig. 2B), the chl a-specific DMSP content also increased in the light (Fig. 2C). No differences in intracellular DMSP and chl a content were observed between the oxic and anoxic incubations in the dark. However, extracellular DMSP that was present at the start of the experiment (presumably as a result of the slurry preparation), had almost completely disappeared after $24 \mathrm{~h}$ under oxic, but not under anoxic conditions (Fig. 2D), while DMS was detected only under anoxic conditions (results not shown). These results suggested that extracellular DMS(P) was more rapidly degraded under oxic than under anoxic conditions by bacteria that had ended up in the silica slurries.

To assess the potential degradation rate of DMS and DMSP by bacteria that were present in the sediment at our sampling site, sediment slurries were amended with $7 \mu \mathrm{M}$ DMSP and incubated under light/oxic, dark/oxic and dark/anoxic conditions (Fig. 3). The degradation of DMSP and DMS can be described by the sum of the metabolic activities of the different functional groups of microorganisms present in the sediment (e.g. sulfate-reducing bacteria, methanogens, aerobic heterotrophs), depending on the concentrations of DMSP and DMS according to MichaelisMenten-type kinetics (Van den Berg et al. 1998). Assuming that DMSP and DMS concentrations are not saturating, and biomasses of DMSP- and DMS-degrading microorganisms remain constant, microbial degradation of DMSP and DMS can be described by the following equations:

$$
\begin{gathered}
\frac{\mathrm{d}}{\mathrm{d} t} \operatorname{DMSP}(t)=-\lambda^{\mathrm{P}} \operatorname{DMSP}(t) \\
\frac{\mathrm{d}}{\mathrm{d} t} \operatorname{DMS}(t)=\eta \lambda^{\mathrm{P}} \operatorname{DMSP}(t)-\lambda^{\mathrm{D}} \operatorname{DMS}(t)
\end{gathered}
$$

where $\lambda^{\mathrm{P}}$ and $\lambda^{\mathrm{D}}$ are the overall degradation rate constants of DMSP and DMS, and $\eta$ is the partitioning 

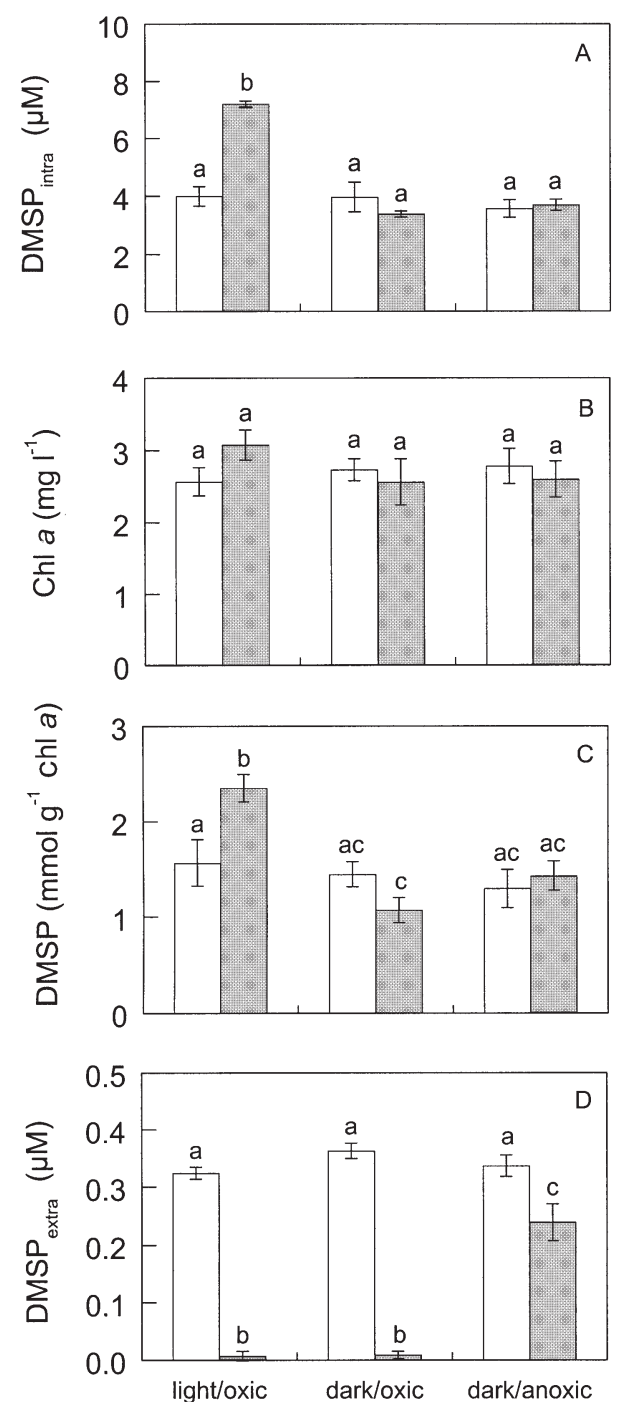

Fig. 2. Intracellular DMSP content (A), chl a (B), chl a-specific DMSP content (C) and extracellular DMSP content (D) in a silica slurry, containing a mixed population of diatoms, incubated under oxic/light, oxic/dark and anoxic/dark conditions. Shown are the means and standard deviations of 4 replicate incubations. White bars: $t=0 \mathrm{~h}$; Gray bars: $t=24 \mathrm{~h}$. Bars with the same letter within each panel are not significantly differ ent, as tested by a 2-way analysis of variance
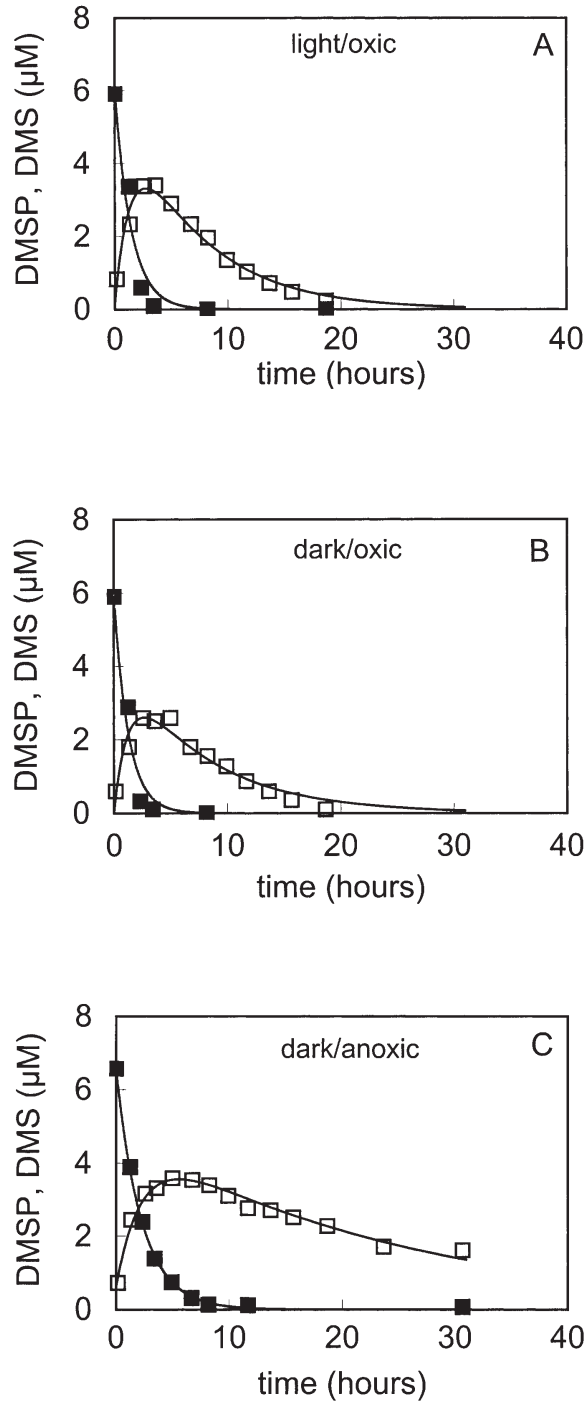

Fig. 3. Degradation of dissolved DMSP and DMS in sediment slurries, under oxic/light (A), oxic/dark (B) and anoxic/dark (C) conditions. D: DMSP concentration; O: DMS concentration. Curves correspond to the model predictions. The graphs show 1 of 2 duplicate experiments (Series A); the other duplicates (Series B) gave similar results. Estimated parameter values: see Table 2

Table 2. Estimated parameter values for Eqs. (3) \& (4), based on non-linear regression and the least-sum-of-squares criterion. $\mathrm{R}^{2}$ in the 4 th and the last column indicate the goodness of fit for DMSP and DMS, respectively. A and B are duplicate incubations

\begin{tabular}{|lcccccccc|}
\hline Condition & & $\begin{array}{c}\text { DMSP(0) } \\
(\mu \mathrm{\mu M})\end{array}$ & $\begin{array}{c}\mathrm{DMSP} \\
\lambda^{\mathrm{P}} \\
\left(\mathrm{d}^{-1}\right)\end{array}$ & $\mathrm{R}^{2}$ & $\begin{array}{c}\mathrm{DMS}(0) \\
(\mu \mathrm{M})\end{array}$ & $\begin{array}{c}\mathrm{DMS} \\
\lambda^{\mathrm{D}} \\
\left(\mathrm{d}^{-1}\right)\end{array}$ & $\mathrm{R}^{2}$ \\
\hline Light/oxic & $\mathrm{A}$ & 6.1 & 16.80 & 0.95 & 0.13 & 3.60 & 0.81 & \\
& $\mathrm{~B}$ & 5.6 & 22.32 & 0.99 & 0.44 & 5.52 & 0.82 & 0.98 \\
Dark/oxic & $\mathrm{A}$ & 6.0 & 18.96 & 0.97 & -0.005 & 3.36 & 0.62 & 0.92 \\
& $\mathrm{~B}$ & 7.3 & 16.08 & 0.98 & 0.06 & 2.88 & 0.97 \\
Dark/anoxic & $\mathrm{A}$ & 6.6 & 10.56 & 0.99 & 0.59 & 1.00 & 0.60 & 0.98 \\
& $\mathrm{~B}$ & 6.7 & 11.28 & 0.99 & 0.56 & 0.62 & 0.73 & 0.99 \\
\hline
\end{tabular}


coefficient expressing the fraction of the total DMSP degradation that is cleaved to DMS (mol S in DMS per mol $\mathrm{S}$ in DMSP).

The solutions to the differential Eqs. (1) \& (2) are:

$$
\begin{gathered}
\operatorname{DMSP}(t)=\operatorname{DMSP}(0) \mathrm{e}^{-\lambda^{P_{t}}} \\
\operatorname{DMS}(t)=\operatorname{DMS}(0) \mathrm{e}^{-\lambda^{D t}}+\frac{\lambda^{\mathrm{P}}}{\lambda^{\mathrm{P}}-\lambda^{\mathrm{D}}} \eta \operatorname{DMSP}(0)\left(\mathrm{e}^{-\lambda^{D t}}-\mathrm{e}^{-\lambda^{P^{t}}}\right)
\end{gathered}
$$

$D M S P(0)$ and $D M S(0)$ represent the concentrations of DMSP and DMS at $t=0$. Eqs. (3) \& (4) were fitted to the data from the slurry experiments, using non-linear regression and the least-sum-of-squares criterion. The parameter values thus estimated are shown in Table 2. The model gave an excellent fit to the slurry data (Fig. 3). The results demonstrate that degradation of DMSP and DMS was faster under oxic than under anoxic conditions, while the degradation of DMS was slower than the degradation of DMSP under all conditions (Table 2, Fig. 3). Furthermore, the results show that in this sediment a major part (60 to $82 \%$ ) of the DMSP was not demethylated but cleaved to DMS (Table 2).

\section{DISCUSSION}

Although microbial communities in intertidal sediments are exposed to large diel fluctuations in physicochemical parameters (e.g. oxygen, $\mathrm{pH}$, salinity, light), we found that the total DMS(P) content of the diatomdominated intertidal sediment was nearly constant over a diel cycle. In addition, we found that anoxic conditions during a diel period did not have a strong impact on the intracellular DMSP content of the diatoms. In a natural population, which was isolated from the sediment using a silica slurry, $\mathrm{DMSP}_{\text {intra }}$ and chl a did not change when incubated under dark/oxic or dark/anoxic conditions. The diatoms apparently were able to survive dark/anoxic conditions very well, which is in accordance with earlier findings that estuarine benthic diatoms are able to survive long periods in the dark equally well under oxic or anoxic conditions (Admiraal \& Peletier 1979). Under light/oxic conditions, we observed a significant increase in the chl aspecific DMSP content in the silica slurries. Light clearly had a stimulating effect on DMSP production, but as we have no data on changes in cell numbers, we do not know if the amount of DMSP per cell increased. Possibly, incubation under continuous light affected the chl a content of the diatoms, leading to an increased DMSP:chl a ratio. The DMSP:chl a ratios we observed are similar to the values reported for diatomdominated communities in pelagic systems (Iverson et al. 1989, Kwint \& Kramer 1996, Townsend \& Keller 1996). The DMSP:chl a ratio in the sediment samples (about $5 \mathrm{mmol} \mathrm{g}^{-1}$ ) was much higher than in the silica slurries (about $1.5 \mathrm{mmol} \mathrm{g}^{-1}$ ), which may have been caused by a different species composition and a higher salinity in the sediment samples. The sediment at Ellewoutsdijk was dominated by Gyrosigma accuminatum and salinity was $30 \mathrm{PSU}$, while the sediment used for the silica slurry experiment was dominated by Navicula arenaria var. rostellata and salinity was 20 PSU. Several studies have demonstrated an increase in DMSP content with increasing salinity in marine diatoms (Dickson \& Kirst 1986b, Nothnagel 1995, Van Bergeijk 2000).

DMSP excreted by microphytobenthos can be degraded by the bacterial community in the sediment. We found that degradation of DMSP and DMS in sediment slurries was quite fast and that it was very well described by the applied equations (Fig. 3). This implies that degradation followed 1st order kinetics and was not saturated by the concentration of DMSP $(7 \mu M)$ added. Degradation of DMSP and DMS was fastest under light/oxic conditions. The slightly slower degradation of DMSP and the lower $\eta$ (the proportion of DMSP which is cleaved to DMS) under dark/oxic conditions might be explained by the activity of purple sulfur bacteria, which are generally found in significant numbers in marine intertidal sediments (e.g. Visscher \& Van Gemerden 1991). It has been observed that the DMSP lyase activity of the purple sulfur bacterium Thiocapsa roseopersicina M11 is enhanced in the light under oxic conditions (Jonkers et al. 1998b). Marine microalgae have also been shown to contain DMSP lyase (Stefels \& Van Boekel 1993, Steinke et al. 1996), but it is unknown whether their DMSP lyase activity is dependent on light conditions and there are indications that marine diatoms do not have DMSP lyase (Stefels et al. 1995, Kwint et al. 1996, Van Bergeijk 2000). The DMS-oxidizing activity of purple sulfur bacteria in the light may also explain the difference between the degradation of DMS under light/oxic and dark/oxic conditions (Jonkers et al. 1999). In most studies, the degradation of DMS in marine sediment slurries has been found to be quite similar under oxic or anoxic conditions (Kiene 1988, Visscher et al. 1995). However, under dark/anoxic conditions the degradation of DMSP and especially of DMS in our slurry experiments was much slower than under dark/oxic and light/oxic conditions. Similar to our findings, Lomans et al. (1999) have found a 10-fold higher degradation rate of DMS under oxic compared to anoxic conditions in freshwater sediment slurries. Furthermore, Jonkers et al. (1998a) detected DMS only in small flux chambers over sediment cores that were incubated in the dark with an $\mathrm{N}_{2}$ atmosphere, but not in those that were incubated in the light with an air atmosphere. 
In the dark, photosynthetic oxygen production ceases in the sediment and thus the thickness of the oxygenated layer decreases. Considering the faster degradation of DMSP and DMS under light/oxic conditions in the sediment slurries, an increase of the $\operatorname{DMS}(\mathrm{P})_{\text {porewater }}$ concentration in the dark was expected. However, in our study we did not observe a difference in $\operatorname{DMS}(\mathrm{P})_{\text {porewater }}$ concentrations in the sediment in the light or the dark. One explanation might be that we do not know exactly from which depth of the sediment the porewater was collected, as a consequence of the method used for porewater collection (see 'Materials and methods'). If porewater was collected from a layer which was relatively thick compared to the thickness of the oxic layer, then the effect of a relatively low $\mathrm{DMS}(\mathrm{P})_{\text {porewater }}$ concentration in the oxic layer may not have been noticed in the average $\operatorname{DMS}(\mathrm{P})_{\text {porewater }}$ concentration that we measured. A second explanation for the constant $\operatorname{DMS}(\mathrm{P})_{\text {porewater }}$ concentration might be that the maximum excretion rate of DMSP from the diatoms is much lower than the potential degradation rate of dissolved DMSP under all conditions. In that case, the standing concentration of DMSP in the porewater will always be low.

The observation that $\mathrm{DMS}(\mathrm{P})_{\text {total }}$ and $\mathrm{DMS}(\mathrm{P})_{\text {porewater }}$ remained nearly constant in the light and in the dark indicated that DMS(P) production and consumption processes were in equilibrium in the light and in the dark. However, heavy rainfall at the end of the low water period in the dark caused a sudden increase in the extracellular DMS(P) concentration. Presumably, this is caused by excretion of DMSP by the diatoms on the sediment surface, which were exposed to an osmotic downshock. Excretion of DMSP as a response to an osmotic downshock has been observed in the Prasinophyte alga Tetraselmis subcordiformis (Dickson \& Kirst 1986a) and in the estuarine benthic diatom Cylindrotheca closterium (Van Bergeijk 2000), and it is assumed that this is part of a mechanism of osmoacclimation.

Our results show that, although DMS(P) may accumulate in the anoxic layer of the sediment, due to a relatively slow degradation under anoxic conditions, it will be largely consumed in the oxic layer when it diffuses towards the sediment surface. This hypothesis is confirmed by several reports on direct flux measurements in intact intertidal sediment cores under an air atmosphere, which showed no differences in DMS fluxes under light or dark conditions (Jørgensen \& OkholmHansen 1985, Harrison et al. 1992, Bodenbender et al. 1999). Harrison et al. (1992) and Cerqueira \& Pio (1999) have measured in situ DMS fluxes from emersed intertidal sediments of around $100 \mathrm{nmol} \mathrm{m} \mathrm{m}^{-2} \mathrm{~h}^{-1}$. This is in the same order of magnitude as fluxes calculated for seas and oceans (see references in Cerqueira \& Pio
1999), despite the much higher DMSP contents of intertidal sediments compared to pelagic ecosystems.

We suggest that the low flux of DMS from intertidal sediments is caused by a relatively low turnover of particulate DMSP and a relatively high turnover of dissolved DMSP and DMS in intertidal sediments. To illustrate this point, we estimated the turnover rates of dissolved DMS(P) and particulate DMSP. The degradation rate constants of dissolved DMS(P) under oxic conditions at our sampling site were 105 to $117 \mathrm{~d}^{-1}$ for DMSP and 19 to $27 \mathrm{~d}^{-1}$ for DMS in sediment (Table 2: values multiplied by 6 to correct for a 6 -fold dilution of the sediment in the slurries), compared to an average of about $10 \mathrm{~d}^{-1}$ for DMSP (Kiene 1996) and 0.3 to $2 \mathrm{~d}^{-1}$ for DMS (Simó \& Pedrós-Alió 1999) in seawater. Thus, turnover rates of dissolved DMS(P) in our intertidal sediment system are approximately 1 order of magnitude higher than the values reported for seawater. This might be explained by the fact that population densities of microorganisms, including those responsible for DMS(P) degradation, are generally orders of magnitude higher in intertidal sediment ecosystems than in open seawater. To estimate the turnover of particulate DMSP, we make use of our observation that the concentration of DMS(P) in the porewater was constant over a diel cycle, indicating that production and consumption were in balance. Combining a porewater concentration of DMS(P) of ca. $100 \mathrm{nM}$ (Fig. 1) with a turnover rate of dissolved DMSP of ca. $110 \mathrm{~d}^{-1}$, the degradation rate of dissolved DMSP would be $100 \mathrm{nM} \times 110 \mathrm{~d}^{-1}=11 \mu \mathrm{M}$ DMSP $d^{-1}$. Hence, release of dissolved DMSP from particulate DMSP would also be ca. $11 \mu \mathrm{M} \mathrm{d}^{-1}$. As the content of particulate DMSP in the sediment was about $100 \mu \mathrm{M}$, this implies a turnover rate of particulate DMSP of ca. $0.1 \mathrm{~d}^{-1}$. Using data from pelagic systems (Kiene 1996, Ledyard \& Dacey 1996, Van Duyl et al. 1998) turnover rates of particulate DMSP of 0.14 to $2 \mathrm{~d}^{-1}$ were calculated. This reveals that, indeed, the turnover rate of particulate DMSP in our intertidal sediment ecosystem is lower than the values reported for seawater.

In conclusion, we found that although intertidal sediments contain high total amounts of DMSP, a relatively low amount of DMS(P) is detected in the porewater and therefore no large fluxes of DMS to the atmosphere are to be expected from intertidal sediments. Under naturally fluctuating light and oxygen conditions only small amounts of DMSP are released by the diatoms, and once released, DMSP and DMS are rapidly degraded in the upper oxygenated sediment. Disturbances, however, like osmotic shocks caused by rainfall, can lead to a transient accumulation of DMS(P) in porewater and possibly to a higher flux of DMS to the atmosphere. 
Acknowledgements. We are grateful to Doris Slezak, Arjan Kop and Fleur van Duyl (NIOZ, Texel, The Netherlands) for their assistance with the DMS(P) measurements using their purge-and-trap system. We thank the anonymous referees for their helpful comments. The investigations of S.A.v.B. were supported by the Netherlands Organization for Scientific Research (NWO), grant 770-50-245. J.H. was supported by the Earth and Life Sciences Foundation (ALW), which is subsidized by NWO. This is publication no. 2960 of the Netherlands Institute of Ecology (NIOO-KNAW)

\section{LITERATURE CITED}

Admiraal W, Peletier H (1979) Sulphide tolerance of benthic diatoms in relation to their distribution in an estuary. $\mathrm{Br}$ Phycol J 14:185-196

Andreae MO, Elbert W, Demora SJ (1995) Biogenic sulfur emissions and aerosols over the tropical South Atlantic 3. Atmospheric dimethylsulfide, aerosols and cloud condensation nuclei. J Geophys Res 100:11335-11356

Ayers GP, Cainey JM, Gillet RW, Ivey JP (1997) Atmospheric sulphur and cloud condensation nuclei in marine air in the Southern Hemisphere. Philos Trans R Soc Lond B Biol Sci 352:203-211

Bates TS, Lamb BK, Guenther A, Dignon J, Stoiber RE (1992) Sulfur emissions to the atmosphere from natural sources. J Atmos Chem 14:315-317

Blanchard GF, Guarini JM, Gros P, Richard P (1997) Seasonal effect on the relationship between the photosynthetic capacity of intertidal microphytobenthos and temperature. J Phycol 33:723-728

Blunden G, Smith BE, Irons MW, Yang MH, Roch OG, Patel AV (1992) Betaines and tertiairy sulphonium compounds from 62 species of marine algae. Biochem Syst Ecol 20: $373-388$

Bodenbender J, Wassmann R, Papen H, Rennenberg H (1999) Temporal and spatial variation of sulfur-gas-transfer between coastal marine sediments and the atmosphere. Atmos Environ 33:3487-3502

Brugger A, Slezak D, Obernosterer I, Herndl GJ (1998) Photolysis of dimethylsulfide in the northern Adriatic Sea: dependence on substrate concentration, irradiance and DOC concentration. Mar Chem 59:321-331

Cerqueira MA, Pio CA (1999) Production and release of dimethylsulphide from an estuary in Portugal. Atmos Environ 33:3355-3366

Challenger F, Bywood R, Thomas P, Hayward BJ (1957) Studies on biological methylation. XVII. The natural occurrence and chemical reactions of some thetins. Arch Biochem Biophys 69:514-523

Charlson RJ, Wigley TML (1994) Sulfate aerosol and climatic change. Sci Am 270:28-35

Charlson RJ, Lovelock JE, Andreae MO, Warren SG (1987) Oceanic phytoplankton, atmospheric sulphur, cloud albedo and climate. Nature 326:655-661

De Winder B, Staats N, Stal LJ, Paterson DM (1999) Carbohydrate secretion by phototrophic communities in tidal sediments. J Sea Res 42:131-146

Dickson DMJ, Kirst GO (1986a) The role of b-dimethylsulphoniopropionate, glycine betaine and homarine in the osmoacclimation of Platymonas subcordiformis. Planta 167: $536-543$

Dickson DMJ, Kirst GO (1986b) Osmotic adjustment in marine eukaryotic algae: the role of inorganic ions, quarternary ammonium, tertiary sulphonium and carbohydrate solutes. I. Diatoms and a rhodophyte. New Phytol 106: 645-655

Harrison RM, Nedwell DB, Shabbeer MT (1992) Factors influencing the atmospheric flux of reduced sulfur compounds from North Sea inter-tidal areas. Atmos Environ 26: 2381-2387

Iverson RL, Nearhoof FL, Andreae MO (1989) Production of dimethylsulfonium propionate and dimethylsulfide by phytoplankton in estuarine and coastal waters. Limnol Oceanogr 34:53-67

Jonkers HM, Koopmans GF, van Gemerden H (1998a) Dynamics of dimethyl sulfide in a marine microbial mat. Microb Ecol 36:93-100

Jonkers HM, de Bruin S, van Gemerden H (1998b) Turnover of dimethylsulfoniopropionate (DMSP) by the purple sulfur bacterium Thiocapsa roseopersicina M11: ecological implications. FEMS Microbiol Ecol 27:281-290

Jonkers HM, Jansen M, van der Maarel MJEC, van Gemerden $H$ (1999) Aerobic turnover of dimethyl sulfide by the anoxygenic phototrophic bacterium Thiocapsa roseopersicina. Arch Microbiol 172:150-156

Jørgensen BB, Okholm-Hansen B (1985) Emissions of biogenic sulfur gases from a Danish estuary. Atmos Environ 19:1737-1749

Keller MD, Bellows WK, Guillard RRL (1989) Dimethyl sulfide production in marine phytoplankton. In: Saltzman ES, Cooper WJ (eds) Biogenic sulfur in the environment. American Chemical Society, Washington, DC, p 167-200

Kelly DP, Smith NA (1990) Organic sulfur compounds in the environment: biogeochemistry, microbiology, and ecological aspects. In: Marshall KC (ed) Advances in microbial ecology. Plenum Press, New York, p 345-385

Kiene RP (1988) Dimethyl sulfide metabolism in salt marsh sediments. FEMS Microbiol Ecol 53:71-78

Kiene RP (1996) Turnover of dissolved DMSP in estuarine and shelf waters of the northern Gulf of Mexico. In: Kiene RP, Visscher PT, Keller MD, Kirst GO (eds) Biological and environmental chemistry of DMSP and related sulfonium compounds. Plenum Press, New York, p 337-349

Kwint RLJ, Kramer KJM (1996) The annual cycle of the production and fate of DMS and DMSP in a marine coastal system. Mar Ecol Prog Ser 134:217-224

Kwint RLJ, Irigoien X, Kramer KJM (1996) Copepods and DMSP. In: Kiene RP, Visscher PT, Keller MD, Kirst GO (eds) Biological and environmental chemistry of DMSP and related sulfonium compounds. Plenum Press, New York, p 239-252

Ledyard KM, Dacey JWH (1996) Kinetics of DMSP-lyase activity in coastal seawater. In: Kiene RP, Visscher PT, Keller MD, Kirst GO (eds) Biological and environmental chemistry of DMSP and related sulfonium compounds. Plenum Press, New York, p 325-335

Lomans BP, den Camp HJMO, Pol A, Vogels GD (1999) Anaerobic versus aerobic degradation of dimethyl sulfide and methanethiol in anoxic freshwater sediments. Appl Environ Microbiol 65:438-443

Nothnagel J (1995) The effects of salinity and light intensity on the osmolyte concentration, cell volumes and growth rates of the Antarctic sea-ice diatoms Chaetoceros sp. and Navicula sp. with emphasis on the amino acid proline. PhD thesis, Rep Polar Res 161, Bremerhaven

Revsbech NP, Sørensen J, Blackburn TH, Lomholt JP (1980) Distribution of oxygen in marine sediments measured with microelectrodes. Limnol Oceanogr 25:403-411

Simó R, Pedrós-Alió C (1999) Short-term variability in the open ocean cycle of dimethylsulfide. Global Biogeochem Cycles 13:1173-1181 
Stefels J, Van Boekel WHM (1993) Production of DMS from dissolved DMSP in axenic cultures of the marine phytoplankton species Phaeocystis sp. Mar Ecol Prog Ser 97: $11-18$

Stefels J, Dijkhuizen L, Gieskes WWC (1995) DMSP-lyase activity in a spring phytoplankton bloom off the Dutch coast, related to Phaeocystis sp. abundance. Mar Ecol Prog Ser 123:235-243

Steinke M, Daniel C, Kirst GO (1996) DMSP lyase in marine macro- and microalgae: intraspecific differences in cleavage activity. In: Kiene RP, Visscher PT, Keller MD, Kirst GO (eds) Biological and environmental chemistry of DMSP and related sulfonium compounds. Plenum Press, New York, p 317-324

Taylor BF, Gilchrist DC (1991) New routes for aerobic biodegradation of dimethylsulfoniopropionate. Appl Environ Microbiol 57:3581-3584

Taylor BF, Visscher PT (1996) Metabolic pathways involved in DMSP degradation. In: Kiene RP, Visscher PT, Keller MD, Kirst GO (eds) Biological and environmental chemistry of DMSP and related sulfonium compounds. Plenum Press, New York, p 265-276

Townsend DW, Keller MD (1996) Dimethylsulfide (DMS) and dimethylsulfoniopropionate (DMSP) in relation to phytoplankton in the Gulf of Maine. Mar Ecol Prog Ser 137: 229-241

Van Bergeijk SA (2000) Production of dimethylsulfoniopropionate and dimethylsulfide in intertidal sediment ecosystems. PhD thesis, University of Amsterdam

Van Bergeijk SA, Stal LJ (1996) The role of oxygenic phototrophic microorganims in production and conversion of dimethylsulfoniopropionate and dimethylsulfide in microbial mats. In: Kiene RP, Visscher PT, Keller MD, Kirst GO

Editorial responsibility: Otto Kinne (Editor),

Oldendorf/Luhe, Germany (eds) Biological and environmental chemistry of DMSP and related sulfonium compounds. Plenum Press, New York, p 369-379

Van den Berg HA, Jonkers HM, Van Bergeijk SA, Kooijman SALM (1998) Dimethyl sulfide emissions from a sedimental microbial ecosystem subject to diel variations of oxic and anoxic conditions: a simple mathematical model. FEMS Microbiol Ecol 26:1-16

Van der Maarel MJEC, Hansen TA (1996) Anaerobic microorganisms involved in the degradation of DMS(P). In: Kiene RP, Visscher PT, Keller MD, Kirst GO (eds) Biological and environmental chemistry of DMSP and related sulfonium compounds. Plenum Press, New York, p 351-360

Van Duyl FC, Gieskes WWC, Kop AJ, Lewis WE (1998) Biological control of short-term variations in the concentration of DMSP and DMS during a Phaeocystis spring bloom. J Sea Res 40:221-231

Visscher PT, Van Gemerden H (1991) Production and consumption of dimethylsulfoniopropionate in marine microbial mats. Appl Environ Microbiol 57:3237-3242

Visscher PT, Quist P, Van Gemerden H (1991) Methylated sulfur compounds in microbial mats: in situ concentrations and metabolism by a colorless sulfur bacterium. Appl Environ Microbiol 57:1758-1763

Visscher PT, Kiene RP, Taylor BF (1994) Demethylation and cleavage of dimethylsulfoniopropionate in marine intertidal sediments. FEMS Microbiol Ecol 14:179-190

Visscher PT, Taylor BF, Kiene RP (1995) Microbial consumption of dimethyl sulfide and methanethiol in coastal marine sediments. FEMS Microbiol Ecol 18:145-154

White RH (1982) Analysis of dimethyl sulfoniom compounds in marine algae. J Mar Res 40: 529-536

Submitted: April 30, 2001; Accepted: October 25, 2001

Proofs received from author(s): March 19, 2002 